\title{
Konsep Ganjaran (Tsawāb) Sebagai Alat Pendidikan Menurut Al-Qur'an
}

\section{Hamdan Hasibuan ${ }^{1}$}

\section{Email: hamdan.hasibuan@gmail.com}

\begin{abstract}
Deserts is one of the education appliance. Become, by itself intend deserts is as a means of to educate child so that child can feel to like because deed or its his/its get appreciation. Generally, child know that work or his/its deed which cause he get deserts is goodness. Education appliance is matter which do not just only load the condition of conducive executing of educative work, but can in the form of situation or deed, causing spirit of newly to educative participant in reaching the target of education. Allah also often wear deserts as motivation to human being to do to kindliness in laid open Alquran with term tsawāb.
\end{abstract}

\begin{abstract}
Abstrak
Ganjaran adalah salah satu alat pendidikan. maksudnya ganjaran sebagai alat untuk mendidik supaya anak dapat merasa senang karena perbuatan atau pekerjannya mendapat penghargaan. Anak secara umum mengetahui bahwa pekerjaan baiknya menjadi sebab kenapa ia mendapat ganjaran baik. Alat pendidikan adalah hal yang tidak hanya saja memuat kondisi-kondisi yang memungkinkan terlaksananya pekerjaan mendidik, tetapi dapat berupa perbuatan atau situasi, sehingga menimbulkan semangat baru bagi peserta didik dalam mencapai tujuan pendidikan. Allah juga sering memakai ganjaran sebagai motivasi kepada manusia untuk berbuat kebaikan dalam Alquran yang diungkapkan dengan term tsawāb.
\end{abstract}

Kata kunci: Ganjaran, alat pendidikan dalam Al-Qur'an.

\section{PENDAHULUAN}

Alat pendidikan adalah segala sesuatu yang membantu terlaksananya pendidikan dalam mencapai tujuannya baik berupa benda maupun bukan benda. Alat pendidikan yang berupa benda atau materi adalah berupa benda nyata yang dapat dilihat dengan mata kepala dan dapat diraba dengan indra kulit seperti papan tulis. Sedangkan alat pendidikan yang tergolong kepada yang bukan benda, yaitu alat yang tidak bisa dilihat oleh mata, dan tidak bisa diraba oleh kulit, tetapi bisa didengar oleh telinga, dan dirasakan oleh perasaan, sehingga akan muncul dorongan

\footnotetext{
${ }^{1}$ Dosen Institut Agama Islam Negeri Padangsidimpuan
} 
bagi peserta didik untuk meraih prestasi yang lebih baik. Itulah yang disebut salah satu alat pendidikan dalam Islam, yaitu ganjaran atau reward. ${ }^{2}$

Pendidik dapat memakai ganjaran sebagai salah satu alat perndidikan untuk memotivasi peserta didik agar meningkatkan prestasi yang telah diraihnya. Ganjaran adalah alat pendidikan preventif dan represif yang menyenangkan dan bisa menjadi pendorong dan motivator belajar bagi murid.Ganjaran adalah hadiah terhadap perilaku baik dari anak didik dalam proses pendidikan.

Dari uraian di atas dapat dipahami bahwa ganjaran bertujuan untuk memotivasi peserta didik agar lebih meningkatkan usahanya untuk mendapatkan hasil yang lebih baik dari yang sebelumnya.

Melihat dari konsep ganjaran di atas ternyata Allah juga sering memakai ganjaran sebagai motivasi kepada manusia untuk berbuat kebaikan. Ganjaran dalam Alquran disebut $t s a w a ̄ b$.

Dalam bahasa Arab ganjaran diistilahkan dengan tsawāb. Kata tsawāb berarti pahala, upah dan balasan, khususnya ketika kitab suci berbicara tentang apa yang akan diterima oleh seseorang, baik di dunia maupun di akhirat. dan dalam buku Abdulrahman Saleh Abdullah menyatakan bahwa istilah $t s a w \bar{a} b$ sama dengan ganjaran. ${ }^{3}$

Jadi dapat diambil kesimpulan bahwa tsawāb berarti ganjaran. ata ganjaran dipakai oleh manusia sebagai alat pendidikan. sementara kata tsawāb dipakai oleh Allah dalam Alquran. Disamping itu kata $t s a w \bar{a} b$ juga dipaki untuk mendidik hambanya.

\section{PEMBAHASAN}

Dalam proses mempersiapkan generasi penerus yang sesuai dengan nilai-nilai ilahiyah, pendidikan harus mampu membentuk pribadi peserta didik dengan acuan nilai-nilai ilahiyah. Dalam arti sederhana, dengan demikian pendidikan sering diartikan sebagai usaha manusia untuk membina kepribadian sesuai dengan nilai-nilai di dalam masyarakat dan kebudayaan.

${ }^{2}$ Hafi Anshari dalam Buku,Bukhari Umar, Ilmu Pendidikan Islam, (Batusangkar: STAIN Batusangkar Press, 2005), h. 68

${ }^{3}$ Armai Arief, Pengantar Ilmu Dan Metodologi Pendidikan Islam, (Jakarta: Ciputat Pers, 2002), h. 125-127 
Untuk mengemban potensi kreativitas peserta didik yang bertujuan untuk mewujudkan manusia yang cerdas, terampil, memiliki etos kerja yang tinggi, berbudi pekerti yang luhur, mandiri, beriman dan bertaqwa kepada Tuhan yang maha Esa, dibutuhkan pendidikan.

Pendidikan berperan sebagai sarana dalam membentuk dan membina kepribadian seseorang dalam membimbing dan mengarahkan manusia ke arah yang lebih baik agar memiliki akhlak yang mulia.

Para pendidik dituntut untuk menyempurnakan alat-alat pendidikan. Keterampilan seorang pendidik dalam pemakaian alat-alat pendidikan banyak menentukan kesuksesan proses pembelajaran. Alat pendidikan juga bisa memotivasi peserta didik dalam proses pembelajaran, sebab rangsangan-rangsangan yang bagus kepada peserta didik dalam proses pembelajaran, akan membangkitkan semangat belajar bagi peserta didik, sehingga apa yang diajarkan pendidik kepada peserta didik dapat ditangkap dengan baik. motivasi merupakan salah satu energi yang terpenting dari semua prinsip belajar. Manusia biasanya tidak mau belajar, kecuali bila ada persoalan yang dapat membangkitkan motivasinya untuk mencari solusi dari persoalan itu. Ganjaran itu sebagai alat untuk mendidik agar yang dididik merasa senang karena perbuatan atau pekerjaannya mendapat penghargaan. Selanjutnya pendidik, bermaksud agar dengan ganjaran, anak menjadi lebih giat lagi untuk memperbaiki prestasi yang telah didapatkannya. Dengan kata lain, anak menjadi lebih keras kemauannya untuk bekerja atau berbuat yang lebih baik lagi. ${ }^{4}$

Dalam kamus umum bahasa Indonesia disebutkan bahwa "ganjaran"adalah 1. Hadiah sebagai pembalas jasa.

Dari pengertian ini dapat dipahami bahwa ganjaran dalam bahasa Indonesia bisa dipakai untuk balasan yang baik maupun balasan yang buruk. Adapun yang penulis bahas dalam penelitian ini adalah ganjaran sebagai balasan dari perbuatan baik yang diungkap dalam term (tsawāb) oleh Allah dalam Alquran.

Sementara itu dalam bahasa Arab "ganjaran" diistilahkan dengan "tsawāb" kata tsawāb bisa juga berarti "pahala", upah dan balasan. khususnya ketika kitab suci ini berbicara tentang apa yang akan diterima oleh seseorang baik di dunia maupun di akhirat dari amal perbuatannya.

${ }^{4}$ M. Ngalim Purwanto, Ilmu Pendidikan Teoritis dan Praktis, cet, ke-6,(Bandung: Remaja Rosda Karya, 2009), h. 182 
Allah SWT memberikan ganjaran kepada manusia sesuai dengan apa yang Dia inginkan dan usaha yang ia lakukan dengan term tsawāb.

Tsawāb sebagai ganjaran yang berikan Allah kepada manusia di dalam Alquran sebagai alat pendidikan yang menyenangkan untuk memotivasi agar manusia selalu berusaha dan bersyukur kepada Allah SWT.

Melihat fenomena dalam masyarakat baik bagi guru ataupun bagi orang tua di rumah, sangat sulit sekali bagi mereka memberikan ganjaran kepada anak atau peserta didik ketika anak melakukan suatu pekerjaan dengan baik, sementara sangat mudah bagi guru ataupun orang tua untuk memeberikan hukuman kepada anak didik, baik di rumah maupun di sekolah, ketika mereka melakukan kesalahan, hal ini jelas sangat bertentangan dengan konsep ganjaran dalam pendidikan baik secara umum ataupun menurut Alquran.

Alquran adalah sumber utama dalam pendidikan Islam, sementara yang dijadikan sumber pendidikan Islam itu adalah secara umum, berdasarkan itu penulis merasa sangat perlu membahas sumber pendidikan berdasarkan Alquran khususnya yang membahas tentang ganjaran yang di ungkapkan dalam term tsawāb sebagai alat pendidikan menurut Alquran.

Alquran sebagai petunjuk bagi manusia yang di dalamnya terdapat banyak konsep ganjaran, di mana bisa dijadikan pedoman baik dalam dunia pendidikan ataupun di dalam rumah tangga, namun yang penulis temukan hanya konsep ganjaran Al-Ajr, belum ada pembahasan khusus tentang konsep ganjaran tsawāb tersebut.ini merupakan suatu masalah, suatu hal yang seharusnya dibahas tetapi kenyataannya belum ada pembahasannya. ${ }^{5}$

Konsep adalah sesuatu yang abstrak dan mempunyai hubungan erat dengan fakta atau realita yang ada. ${ }^{6}$

Sedangkan konsep yang dimaksud dalam hal ini adalah konsep ganjaran (tsawāb) yang terdapat di dalam Alquran.Ganjaran adalah hadiah (pembalas jasa) dan balasan (hukuman dan sebagainya). Adapun ganjaran yang penulis maksud dalam penulisan ini adalah ganjaran dalam bentuk balas jasa yang diungkap dalam term (tsawāb) yang terdapat di dalam Alquran.

\footnotetext{
${ }^{5}$ Samsul Nizar, Filsafat Pendidikan Islam, (Jakarta: Ciputat Pers, 2002), h. 34

${ }^{6}$ Masri Singarimbun dan Sofain Efend, Motode Penelitian Survai, (Jakarta: PT. Midas Surya Grafindo, 1989), h. 33
} 
Hasan Langgulung juga memakai kata tsawāb untuk menggantikan kata ganjaran.Kata tsawāb digunakan pada berbagai ayat dalam Alquran yang berarti sesuatu yang diperoleh seseorang dalam hidup ini atau di akhirat karena telah mengerjakan amal kebajikan (pahala).

\section{Macam-Macam Ganjaran}

Untuk menentukan ganjaran macam apakah yang baik diberikan kepada anak merupakan suatu hal yang sangat sulit, ganjaran sebagai alat pendidikan banyak sekali macamnya:

a. Guru mengangguk-angguk tanda senang dan membenarkan suatu jawaban yang diberikan oleh seorang anak.

b. Guru memberi kata-kata yang menggembirakan (pujian seperti: rupanya sudah baik puala tulisanmu kalau kamu terus berlatih tentu akan lebih baik lagi.

c. Pekerjaan dapat juga menjadi suatu ganjaran. Contoh engkau akan segera saya beri tugas yang lebih sukar sedikit karena yang nomor 3 agak terlalu baik kamu kerjakan.

d. Ganjaran yang ditujukan kepada seluruh kelas sering sangat perlu. Misalnya "karena saya lihat kalian telah bekerja dengan baik dan lekas selesai, sekarang bapak akan mengisahkan sebuah cerita yang bagussekali",ganjaran untuk seluruh kelas dapat juga berupa bernyanyiataupergi berdarmawisata.

e. Ganjaran dapat juga berupa benda-benda yang menyenangkan dan berguna bagi anak-anak. ${ }^{7}$

Dari penjelasan macam-macam ganjaran yang dikemukakan di atas dapat dipahami bahwa ganjaran itu tidak harus dengan harga yang mahal.

Adapun bentuk ganjaran yang dapat diambil dari penjelasan di atas adalah:

a. Pujian

Pujian adalah alat motivasi yang positif, setia orang senang dipuji, tak peduli tua atau muda, apalagi anak-anak senang bila mendapatkan pujian atas pekerjaan yang telah ia selesaikan dengan baik, orang yang dipuji merasa bangga karena kerjanya mendapatkan pujian dari orang lain, apalagi seorang anak didik mendapatkan pujian dari gurunya, seperti kata-kata: kerjamu bagus nak, kerjamu rapi betul, selamat yang nilaimu hari ini jauh lebih baik dari yang sebelumnya, dan sebagainya yang bisa di gunakan untuk memotivasi belajar siswa.

\footnotetext{
${ }^{7}$ M.Ngalim Purwanto, Op.Cit, h. 183
} 


\section{b. Hadiah}

Yang dimaksud dengan hadiah di sini adalah ganjaran yang berbentuk pemberian berupa barang. Ganjaran berbentuk ini disebut juga ganjaran materiil. Ganjaran berupa pemberian barang ini sering mendatangkan pengaruh yang negatif pada belajar murid, yakni bahwa hadiah ini lalu menjadi tujuan dari belajar anak. Anak belajar bukan karena ingin menambah pengetahuan, tetapi belajar karena ingin mendapatkan hadiah. Apabila tujuan untuk mendapatkan hadiah ini tidak bisa tercapai, maka anak akan mundur belajarnya. Oleh karena itu, pemberian hadiah berupa barang ini lebih baik jangan sering dilakukan. Berikan hadiah berupa barang jika dianggap memang perlu, dan pilihlah pada saat yang tepat.

\section{c. Penghormatan}

Ganjaran berupa penghormatan dapat berbentuk dua macam, yaitu: Pertama, berbentuk semacam penobatan, yaitu anak yang mendapat penghormatan diumumkan dan ditampilkan di hadapan teman-temannya, dapat juga di hadapan teman-temannya sekelas, teman-teman sesekolah, atau mungkin juga di hadapan para teman dan para orang tua murid; Kedua, penghormatan berbentuk pemberian kekuasaan untuk melakukan sesuatu, misalnya kepada anak yang berhasil menyelesaikan suatu soalyang sulit, disuruh mengerjakannya di papan tulis untuk dicontoh teman-temannya. Anak yang rajin diserahi wewenang/tugas untuk mengurusi perpustakaan sekolah. Anak-anak yang senang bekerja diberi tugas untuk membantu guru memelihara alat-alat pelajaran, dan sebagainya.

Segala bentuk pemberian yang di lakukan oleh pendidik kepada peserta didik asalkan dalam bentuk hal yang menyenagkan dan akan menimbulkan motivasi pada peserta didik semua itu bisa disebut dengan ganjaran $(t s a w \bar{a} b){ }^{8}$

\section{Syarat-Syarat Ganjaran}

Kalau kita perhatikan apa yang telah diuraikan tentang maksud ganjaran dan tsawāb bagaimana dan siapa yang perlu mendapat ganjaran, serta ganjaran-ganjaran macam apakah yang yang baik diberikan kepada seseorang, ternyata memberikan ganjaran bukanlah soal yang mudah, Ada beberapa syarat yang perlu diperhatikan oleh pendidik:

\footnotetext{
${ }^{8}$ Armai Arief, Op-Cit, h. 127
} 
a. Untuk memberi ganjaran yang paedagogis perlu sekali guru mengenal betul-betul muridmuridnya dan tahu menghargai dengan cepat. Ganjaran dan penghargaan yang salah dan tidak tepat dapat membawa akibat yang tidak diinginkan.

b. Ganjaran yang diberikan kepada seorang anak janganlah hendaknya menimbulkan rasa cemburu atau iri hati bagi anak yang lain yang merasa pekerjaannya juga lebih baik, tetapi tidak mendapat ganjaran.

c. Memberi ganjaran hendaklah hemat, terlalu kerap atau terus menerus memberi ganjaran dan penghargaan akan menjadi hilang arti ganjaran itu sebagai alat pendidikan.

d. Jangan memberi ganjaran dengan menjanjikan lebih dahulu sebelum anak-anak menunjukkan prestasi kerjanya apalagi bagi ganjaran yang d iberikan kepada seluruh kelas. Ganjaran yang telah dijanjikan lebih dahulu, hanyalah akan membuat anak-anak berburu-buru dalam bekerja dan akan membawa kesukaran-kesukaran bagi beberapa orang anak yang kurang pandai.

e. Pendidik harus berhati-hati memberikan ganjaran, jangan sampai ganjaran yang diberikan kepada anak-anak diterimanya sebagai upah dari jerih payah yang telah dilakukan. ${ }^{9}$

Dalam pemberian ganjaran tentu ada syarat-syarat yang harus diperhatikan oleh seorang guru, sehingga tidak salah dalam pemberian ganjaran, akan tetapi pemberian ganjaran dalam term tsawāb tidak diragukan lagi karena yang memakai kata tsawāb itu adalah maha berilmu dan maha bijaksana.

\section{Ganjaran Pahala Bagi Orang-Orang Yang Beramal Saleh Secara Umum}

Ganjaran pahala yang diberikan oleh Allah Swt, bagi orang-orang yang beramal saleh secara umum dijelaskan oleh Allah di dalam beberapa surat di dalam Alquran sebagai berikut:

a. QS. Maryam/19 ayat: 76

Isi kandungan surat ini adalah bahwasanya Allah menambahkan petunjuk kepada orang yang mempergunakan petunjuk petunjuk yang dimilikinya dijalan Allah dan amal saleh lebih baik pahalanya dari pada harta dan anak. Orang-rang yang yang beriman dengan ayat-ayat Allah serta mematuhinya maka Allah akan terus menerus menambah petunjuk kepada mereka yang telah mendapat petunjuk sehingga mereka semakin mampu melakukan kebajikan. ${ }^{10}$

\footnotetext{
${ }^{9}$ M.Ngalim Purwanto, Op. Cit, h. 184

${ }^{10}$ M. Quraish Shihab, Tafsir Al-Misbah Pesan, Kesan, dan Keserasian Alquran, (Jakarta: Lentera Hati, 2002),vol 7, h. 511
} 
1) Penjelasan ayat

Ayat ini menyatakan balasan orang-orang beriman dengan menyatakan.Adapun orang-orang yang beriman terhadap ayat-ayat Allah serta mematuhinya ketika mereka mendengar ayatayat itu maka Allahakan terus menerus menambah petunjuk kepada mereka yang telah mendapat petunjuk sehingga mereka semakin mampu melakukan kebajikan. Dan amal-amal saleh yang kekal itu lebih baik pahalanya di sisi tuhanmu dan lebih baik kesudahannya. ${ }^{11}$

Adapun balasan bagi orang-orang yang beramal saleh dan membubuktikan dengan mempergunakan ilmu yang telah dimilikinya di jalan Allah maka balasan dari Allah adalah menambah petunjuk yang telah ia miliki itu, dan bisa juga berbentuk kenikmatan di akhirat seperti surga.

2) Analisis kependidikan

Dalam ayat di atas Allah memberikan ganjaran yang menyenangkan sebagai motivasi bagi orang-orang yang beriman dan beramal saleh agar selalu menggunakan petunjuk yang telah diberikan oleh Allah sesuai dengan yeng telah diajarkan dalam Alquran sehingga Allah menambah petunjuk yang ada itu.

Dalam proses pendidikan, seorang guru dituntut menggunakan metodik. Metodik adalah suatu cara dan siasat penyampaian bahan pelajaran tertentu dari suatu mata pelajaran agar siswa dapat mengetahui, mamahami, mempergunakan ilmu yang telah ia peroleh. ${ }^{12}$ Dalam menyampaikan pelajaran, guru dituntut untuk menggunakan metodik yang bermacam-macam, dalam hal ini ganjaran adalah salah satu metodik yang sangat tepat digunakan oleh guru, sehingga pelajaran bisa dikuasai dengan baik oleh peserta didik dan mampu mengamalkannya dalam kehidupan sehari-hari.

b. QS. Al-Kahfi/18 ayat: 31

"Mereka Itulah (orang-orang yang) bagi mereka surga 'Adn, mengalir sungai-sungai di bawahnya; dalam surga itu mereka dihiasi dengan gelang mas dan mereka memakai Pakaian hijau dari sutera halus dan sutera tebal, sedang mereka duduk sambil bersandar di atas dipandipan yang indah.Itulah pahala yang sebaik-baiknya, dan tempat istirahat yang indah.

\footnotetext{
${ }^{11}$ M. Qurash Shihab, Op-Cit, vol 7, h. 511

${ }^{12}$ Zakiah Deradjat,Zakiah Daradjat, dkk, Pengajaran Agama Islam, (Jakarta, Bumi Aksara, 1995), h. 1
} 
1) Penjelasan ayat

Sebagaimana kebiasaan Alquran menggandengkan penyebutan sesuai dengan lawannya, ayat ini menyebutkan balasan orang-orang yang beriman, ayat di atas menyebutkan yaitu surga.

Ditempat kediaman mereka itu mengalir sungai-sungai di bawahnya, yakni antara pepohonan dan kediaman-kediaman penghuninya: di samping itu , disana mereka juga dihiasi dengan gelang-gelang yang terbuat dari emas dan perak dan mereka memakai pakaian berwarna hijau dan lain-lain yang terbuat dari sutra halus dan sutra tebal, dan sedang mereka duduk sambil bersandar di atas dipan-dipan berbantal dan bertirai-tirai indah. Itulah sebaik-baik pahala dan tempat istirahat yang indah yang menyiapkan segala macam yang bermanfaat makanan dan minuman, maupun keduanya. ${ }^{13}$

Berdasarkan penjelasan ayat di atas dapat penulis tarik kesimpulan bahwa Allah sebagai pemberi balasan surga, kepada orang-orang yang beriman dan membuktikan keimanannya itu dengan beramal saleh sesuai dengan tuntunan Allah Swt.

2) Hadis yang relevan

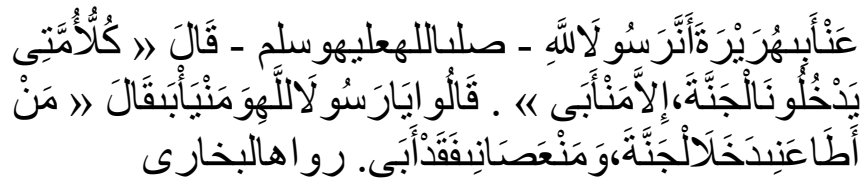

Terjemahan:

Abu Hurairah meriwayatkan bahwa Rasulullah saw. bersabda: Semua umatku akan masuk surga kecuali orang yang aba.Sahabat bertanya, siapa yang abâ itu ya Rasulullah?. Nabi menjawab: orang yang taat kepadaku akan masuk surga sedangkan yang durhaka itulah yang $a b \hat{a}$.

Dalam hadis di atas dijelaskan bahwa seluruh umat Nabi akan masuk ke dalam surga kecuali yang abâ yaitu orang yang durhaka baik durhaka kepada Allah atau kepada Nabi Muhammad saw. Jadi untuk itu dalam hadis ini, Rasul mengingatkan supaya umatnya selalu meningkatkan ibadah dan amal salehnya.

Dalam ayat di atas yang menyatakan tentang ganjaran sorga, Allah memberikan ganjaran untuk memotivasi umat manusia supaya mereka menyakini dan beriman kepada Allah dan Rasul-Nya dan juga supaya mereka tertarik untuk melaksanakan amalan-amalan saleh, Allah menjanjikan dengan tempat yang tinggi di dalam sorga. Allah juga menggambarkan keindahankeindahan sorga yang akan diberikan kepada hamba-Nya.

\footnotetext{
${ }^{13}$ M. Quraish Shihab, Tafsir Al-Misbah Pesan, Kesan, dan Keserasian Alquran, (Jakarta: Lentera Hati, 2002), vol lengkap, h. 286-287
} 
3) Analisis kependidikan

Ayat di atas yang menyatakan ganjaran sorga.Allah memberikan ganjaran untuk memotivasi umat manusia supaya mereka menyakini dan beriman kepada Allah dan juga supaya mereka tertarik untuk melaksanakan amalan-amalan saleh.Allah menjanjikan danmenggambarkan kenikmatandan keindahan-keindahan surga yang akan diberikan kepada hamba-hambanya.

Alangkah baiknya dalam pendidikan bisa pendidikmenggunakan metode khas yang diajarkan oleh Allah langsung melalui Alquran.Bukankah Alquran itu sebagai pedoman dalam hidup kita.Dalam hal ini, Abdurrahman an-Nahlawi menjelaskan, bahwa ganjaran yang diberikan Allah disebut dengan targhib yaitu ganjaran dengan memberikan gambaran yang indah tentang kenikimatan sorga. ${ }^{14}$

Suatu motivasi yang sangat bagus diberikan oleh Allah dengan tempat yang menyenangkan di sorga, suatu keistimewaan bagi yang mau meningkatkan keimanan dan amal salehnya, dalam pembelajaran sangat baik digunakan metode ini kepada peserta didik untuk dapat memberi semangat supaya lebih giat dalam bersaing untuk mendapatkan ganjaran berupa hadiah atau pujian dari pendidik.

\section{Ganjaran Pahala Bagi Orang-Orang Yang Sabar}

Ganjaran pahala bagi orang-orang yang sabar yang diberikan oleh Allah hanya terdapat dalam satu surat yaitu surat: QS. Qashash/28 ayat: 80

"Berkatalah orang-orang yang dianugerahi ilmu: "Kecelakaan yang besarlah bagimu, pahala Allah adalah lebih baik bagi orang-orang yang beriman dan beramal saleh, dan tidak diperoleh pahala itu, kecuali oleh orang- orang yang sabar".

1) Penjelasan ayat

Berkata orang-orang yang dianugerahi Ilmu kepada mereka orang-orang yang tidak dianugerahi Ilmu tentang apa yang telah dijanjikan oleh Allah kelak di akhirat, kecelakaan yang besarlah bagi kalian, pahala Allah di akhirat berupa surga adalah lebih baik bagi orang-orang yang beriman dan beramal saleh dari pada apa yang diberikan Allah kepada Qarun di dunia dan tidak diperoleh pahala itu yakni surga kecuali oleh orang-orang yang sabar, di dalam menjalankan ketaatan dan menjauhi maksiat.

Dalam tafsir Al-Misbah dijelaskan bahwa pahala Allah jauh lebih baik dari pada kemewahan yang dimiliki dan dipamerkan oleh Qarun itu, pahala Allah itu bagi orang yang beriman dan beramal saleh dan tidak diperolehnya pahala itu tidak diamalkan kecuali oleh orang-orang yang sabar dan tabah melaksanakan konsekuensi keimanan dan amal saleh serta menerima ujian dan cobaan dari Allah. ${ }^{15}$

\footnotetext{
${ }^{14}$ Abdurrahman An-Nahlawi, Prinsip-Prinsip dan Metoda Pendidikan Islam, (Bandung: CV. Diponegoro, 1996), h.414

${ }^{15}$ M. Quraish Shihab, Op-Cit, vol 9, h. 671
} 
2) Hadis yang relevan

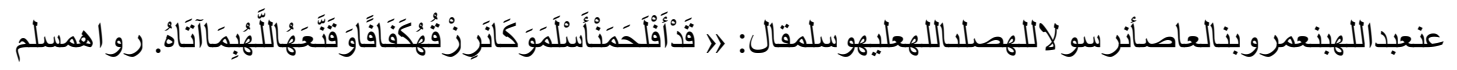

Terjemahan: Dari Abdullah ibn Amru ibn al-'Ash, sesungguhnya Nabi saw. bersabda: Sungguhnya beruntunglah orang yang beragama Islam dan rezkinya cukup dan ia merasa qana'ah (cukup) dengan apa yang diberikan Allah kepadanya.

Dalam ayat dan hadis di atas dijelaskan bahwa allah dan Rasul-Nya memberikan motivasi dalam menanamkan sifat sabar di dalam diri kepada umatnya di dalam ayat ayat dijelaskan orang yang merasa cukup dengan apa yang diberikan kepanya, artinya tidak terlalu mengharapkan harta seperti yang miliki oleh Qarun dan yang diharapkan oleh orang-orang kafir.

\section{3) Analisis kependidikan}

Dalam ayat dan hadis di atas Allah dan Rasul-Nya menggunakan ganjaran sebagai alat pendidikan untuk memotivasi hambanya agar selalu bersabar. Dalam pelaksanaan pendidikan, kesabaran sangat dibutuhkan untuk mencapai apa yang menjadi keinginan.Sabar dan tabah melaksanakan konsekuensi keimanan dan amal saleh serta menerima ujian dan cobaan dari Allah. Dalam hadis, Rasul menjelaskan bahwa keberuntungan bagi orang-orang yang qonaah dan merasa cukup dengan apa yang diberikan kepadanya. Semua ini harus ditanamkan pada tiap diri peserta didik tentu merupakan tanggung jawab dari setiap pendidik.Pendidik secara umum adalah orang yang memiliki tanggungjawab untuk mendidik.Sedangkan secara khusus pendidik dalam perspektif Islam adalah orang yang bertanggungjawab terhadap perkembangan peserta didik dengan mengupayakan perkembangan seluruh potensi. ${ }^{16}$ Berdasarkan pengertian di atas, dapat diahami bahwa pendidik dalam perspektif Islam ialah orang yang bertanggungjawab terhadap upaya perkembangan jasmani dan rohani peserta didik.

\section{Ganjaran Pahala Bagi Orang-Orang Yang Bersyukur}

Ganjaran pahala bagi orang-orang yang bersyukur yang diberikan oleh Allah hanya terdapat dalam satu surat yaitu: QS. Ali-Imran/3 ayat: 145

"Sesuatu yang bernyawa tidak akan mati melainkan dengan izin Allah, sebagai ketetapan yang Telah ditentukan waktunya.barang siapa menghendaki pahala dunia, niscaya kami berikan kepadanya pahala dunia itu, dan barang siapa menghendaki pahala akhirat, kami berikan (pula) kepadanya pahala akhirat itu. dan kami akan memberi balasan kepada orang-orang yang bersyukur.

1) Penjelasan ayat

Artinya tidak ada seorangpun di atas dunia ini yang meninggal dunia melainkan menurut takdir Allahdan sampai ia memenuhi waktu yang telah ditetapkanAllah ta'ala bagi manusia.

\footnotetext{
${ }^{16}$ Samsu Nizar, Filsafat Pendidikan Islam Pendekatan Historis, Teoritis dan Praktis, (Jakarta: Ciputat Pers, 2002),h. 41
} 
(كتبا مؤجل)sebagai ketetapanyang telah ditentukan waktunya. Ayat ini memberikan motivasi bagi umat Islam yang pengecut dan dorongan bagi mereka untuk berperang, karena maju berperang atau mundur dar tidak akan mengurangi atau menamba umur. ${ }^{17}$

Allah akan memberikan pahala dunia kepada orang-orang yang berusaha untuk mendapatkan pahala dunia itu sesuai dengan apa yang telah ditetapkan oleh Allah Swt baginya, dan di akhirat ia tidak akan mendapatkan apa-apa.

Maksud dari ayat ini adalah bahwa Allah akan memberikan sesuai dengan apa yang diinginkan ataupun yang dicita-citakan dan berjuang untuk itu maka akan mendapatkannya, jika dia berjuang semata-mata untuk dunia maka ia juga akan mendapatkannya dan tidak lebih: dia mau kaya, kekayaan akan diberikan. Dia mau pangkat; pangkatpun akan Allah diberikan, dia ingin kemegahan; kemegahanpun akan Allah diberikan, dia ingin kebesaran, kedudukan dan sebagainya dalam dunia ini maka semua itu akan Allah berikan sesuai dengan usaha yang di lakukan banyak usaha tentu banyak pula yang didapat. ${ }^{18}$

Jika tujuannya lebih tinggi dari pada semata-mata dunia yaitu akhirat atau hari depan itupun akan diberikan pula, banyak yang di kehendaki dan banyak pula usaha dan perjuangannya tentu banyak pula yang akan didapat.

Allah akan memberikan pahala akhirat sebagai anugerah atas upaya yang menggunakan nikmat yang telah Allah berikan kepadanya sesuai dengan apa yang telah digariskan oleh Allah, dan memang kami akan memberikan balasan kepada orang-orang yang bersyukur. ${ }^{19}$

Iradat-nya hendak mencapai salah satu dari kedua tujuan ini, baik tujuan dunia semata ataupun tujuan akhirat yang kekal dengan melalui dunia, itulah kelak yang akan menentukan nilai hidup dan nilai mati, kalau hati seseorang semata-mata tertuju keinginan dunia, niscaya dia akan takut mati, sebab hatinya terpaut kepada dunia.

Kebahagiaan dalam dua kehidupan itu ditentukan oleh apa yang dia kehendaki dan citacitakan. Usaha manusia dalam hidup ini berbagai ragam, tetapi kesulitan di dalam mencapai suatu yang dicita-citakan adalah sama antara sekalian orang. cita-cita hidup bukanlah jalan yang selalu datar bertabur bunga, melainkan kadang-kadang disiram dengan air mata dan juga dengan darah.

Sayyid Qhutub lebih jelas mengatakan bahwa yang dimaksud dengan ayat ini adalah orang yang menghendaki pahala dunia saja maka kehidupannya bagaikan kehidupan cacing, binatang melata, dan binatang ternak.

Dari penjelasan di atas sangat merugilah orang-orang yang hidupnya hanya untuk mengharapkan hidup di dunia saja tanpa memperhitungkan tujuan hidup yang lebih kekal dan abadi.

\footnotetext{
${ }^{17}$ Abdullah Bin Muhammad Bin 'Abdulrahman Bin Ishaq Alu Syaikh,Tafsir Ibnu Katsir, (Kairo: Pustaka Imam Asy-Syafi'i, 1994), jilid 5, h. 155

${ }^{18}$ Hamka, Tafsir Al-Azhar, (Jakarta: PT. Pustaka Panjimas, 1987), juz 4, h. 107

${ }^{19}$ M. Quraish Shihab, Op-Cit, vol, 2, h. 236
} 
Kami akan memberikan balasan kepada orang-orang yang bersyukur, yaitu orang-orang yang mengerti nikmat penghormatan ilahi kepada manusia, lalu meningkat derajatnya dari tingkat binatang dan bersyukur kepada Allah atas nikmat itu lalu mereka bangkit menunaikan konsekuensi iman. ${ }^{20}$

Dalam penjelasan ayat di atas dapat penulis ambil kesimpulan bahwa Allah sebagai pemberi ganjaran pahala dunia seperti: kekayaan, kedudukan, pangkat itupun akan Allah berikan, dan pahala akhirat bisa berupa surga dan Allah akan memberikan sesuai dengan ketetapan Allah itupun akan diberikan kepada orang-orang yang bersyukur. Syukur dalam artian menggunakan nikmat yang diberikan Allah sesuai dengan apa yang diperintahkannya.

2) Analisis kependidikan

Dalam ayat di atas, Allah Swt menggunakan ganjaran sebagai motivasi agar hambanya selalu berusaha dan berjuang untuk memperoleh lebih dari sekedar dunia dan semua itu akan didapakan hanya oleh orang-orang yang bersyukur. Semua itu akan di berikan sesuai dengan usaha yang di lakukan banyak usaha tentu banyak pula yang didapat. ${ }^{21}$ Maka seorang guru memiliki tugas memotivasi agar peserta didiknya selalu berusaha sejauh kemampuannya untuk memperoleh hasil yang lebih baik. Motivasi murid adalah menciptakan kondisi sedemikian rupa sehingga peserta didik mau melakukan apa yang dapat dilakukannya. ${ }^{22}$ Dalam hal ini tentu sangat diperlukan keahlian guru dalam menetapkan suatu metode, sehingga murid betul-betul termotivasi untuk melakukan sesuatu yang menjadi tugasnya.

\section{Ganjaran Pahala Bagi Orang-Orang Yang Berbuat Kebaikan}

Ganjaran pahala bagi orang-orang yang berbuat kebaikan diungkapkan oleh Allah hanya terdapat dalam satu surat yaitu:QS. Ali-Imran/3 ayat: 148

"Karena itu Allah memberikan kepada mereka pahala di dunia dan pahala yang baik di akhirat.danAllah menyukai orang-orang yang berbuat kebaikan.

1) Penjelasan ayat

Ayat ini menggambarkan sambutan Allah atas permohonan orang-orang yang berbuat kebaikan. mereka sedemikian tulus berdo'a, optimis kepada pertolongan, bersungguh-sungguh berjuang, dan ta'at kepada Allah dan Rasul mereka maka karena itu Allah menganugrahi mereka pahala dunia, berupa kemenangan, kecukupan, ketenangan batin, nama baik, dan lain-lain, dan pahala yang baik di akhirat, yaitu Surga, keridhahan Allah, dan lain-lain yang tidak dapat di lukiskan dengan kata-kata atau terbetik dalam benak, dan Allah menyukai dan memberi anugerah kepada orang-orang yang berbut kebaikan. ${ }^{23}$

\footnotetext{
${ }^{20}$ Ibid, h. 176

${ }^{21}$ Hamka, Tafsir Al-Azhar, (Jakarta: PT. Pustaka Panjimas, 1987), juz 4, h. 107

${ }^{22}$ Zakiah Deradjat, Op-Cit, h. 140

${ }^{23}$ M.Quraish Shihab, Tafsir Al-Misbah Pesan, Kesan, dan Keserasian Alquran, (Jakarta: Lentera Hati, 2002), vol 2, h. 292
} 
Allah Swt mempersaksikan mereka sebagai orang-orang yang berbuat kebaikan, karenamereka beradap dengan baik dan berjihad dengan baik.Allah menyatakan cinta-Nya kepada mereka sebagai nikmat yang besar dan pahala yang paling besar.

Imam Jalalain Al-Mahilli mengatakan bahwa pahala dunia itu adalah berupa kemenangan dan harta rampasan perang, sedangkan yang sebutkan dengan pahala akhirat maksunya adalah surga, pahala yang baik ialah anugrah yang melebihi dari selayaknya.

Ibnu Katsir menjelaskan bahwa pahala dunia itu ialah pertolongan, kemenangan dan kesudahan yang baik. ${ }^{24}$ Dalam kitab tafsir Al-Azhar di jelaskan ada beberapa syarat yang harus di lakukan manusia ketika permohonan mereka dikabulkan:

a) Tidak mengeluh karena percobaan.

b) Tidak lesuh, pata semangat.

c) Tidak mundur barang setapak

d) Sabar menanti hasil, Walaupun rasanya lama.

e) Senantiasa mengadakan koreksi dan penyelidikan atas dosa terhadap tuhan atau pelanggaranpelanggaran atas disiplin, lalu meperbaikinya. Selalu memohon pertolongan kepada Allah. ${ }^{25}$

Dengan memenuhi keenam syarat ini,balasan Allah pun datang.Permohonan mereka tidak disia-siakan.Mereka diberi kebahagiaan dunia, yaitu kemerdekaan sesudah perbudakan.Cahaya jiwa sesudah kegelapan fikirandan dapat mengatur nasib sendiri di dalam menegakkan agama.kelakakan dapat kebenaran: Allah amat suka kepada orang-orangyang berbuat baik."

Disini sebagai kunci ayat yang diterangkan.Bahwa Allah amat suka, amat kasi kepada orang-orangyang berbuat baik, berbuat kebajikan, atau memperbaiki mana pekerjaanyang belum baik, menyempurnakanmanayang belum sempurna, jatuh dan gagalyang pertama, belumlah kegagalan.Kegagalan.ialah jika jatuh juga, karena sebab yang serupa di tempat yang sama.

Ada tiga halyangsangat penting dijadikan pegangan hidup berjuang:bersyukur, bersabar, selalu memperbaiki dan mempertinggi mutu (Muhsinin), sehingga baik dalam iman atau dalam amal, tidak bertambah mundur, tetapi bertambah maju. ${ }^{26}$

Berdasarkan penjelasan di atas dapat diambil kesimpulan bahwa Allah sebagai pemberi balasan pahala dunia seperti: kemenangan, kecukupan, ketenangan hati nama baik dan pahala akhirat yaitu surga, keridhahan Allah, kepada orang-orang yang berbuat kebaikan yang di buktikan dengan tulus berdo'a, optimis kepada pertolongan Allah, bersungguh-sungguh berjuang, dan taat kepada Allah dan Rasul.

\section{2) Analisis kependidikan}

Dalam ayat di atas, Allah menggunakan motivasi kepada umat-Nya agar selalu berbuat kebaikan.Motivasi yang digunakan Allah adalah berupa ganjaran.Ganjaran adalah alat pendidikan preventif dan represif yang menyenangkan dan bisa menjadi pendorong atau

\footnotetext{
${ }^{24}$ Abdullah Bin Muhammad Bin 'Abdulrahman Bin Ishaq Alu Syaikh, Op-Cit, jilid 2, h. 157

${ }^{25} \mathrm{Hamka}, \mathrm{Op}$-Cit, juzu’ 4, h. 110

${ }^{26} \mathrm{Ibid}$, h. 111
} 
motivator belajar bagi murid. ${ }^{27}$ Seharusnya metode yang digunakan Allah kepada hambanya menjadi acuan bagi guru untuk mendidik peserta didiknya karena Alquran adalah sumber utama dalam pendidikan Islam.dan sangat diharapkan pendidik lebih mengutamakan ganjaran dalam pelaksanaan pendidikan bukannya lebih melaksanakan hukuman karena hukuman akan mebuata peserta didik merasa tidak nyaman.

\section{SIMPULAN}

Ganjaran(tsawāb) yang akan diberikan Allah terdapat di dalam Alquran Setelah dirinci menurut kronologis turunnya surat yang terdapat di dalam Alquran. Makaganjaran terbagi ke dalam beberapa sub tema. Adapun sub tema tersebut adalah: ganjaran pahala kepada orang-orang yang beramal saleh secara umum. Ganjaran ahala kepada orang-orang yang sabar. Ganjaran pahala kepada orang-orang yang bersyukur dan ganjaran pahala kepada orang-orang berbuat kebaikan.

a. Ganjaran Pahala kepada Orang-Orang yang Beramal Saleh Secara Umum.

Ganjaran pahala kepada orang-orang yang beramal saleh ini digambarkan oleh Allah dalam Alquran. Surat al-Maryam/19 ayat: 76, al-Kahfi/18 ayat: 31, 46, dan Ali- Imran/3 ayat: 195. Bahwa Allah akan memberikan bagi mereka itu pahala Surga di akhirat dan menambahkan petunjuk jadi tsawāb sebagai alat pendidikan yang diberikan Allah kepada orang yang beramal saleh untuk memotivasi hambanya dalam menggunakan petunjuk yang telah diberikan Allah.

b. Ganjaran Pahala kepada Orang-Orang yang Sabar.

Ganjaran pahala bagi orang-orang yang sabar digambarkan oleh Allah dalam Alquran. Surat al-Qashash/28 ayat: 80 bahwa mereka akan mendapatkan surga, yang jauh lebih baik daripada kemegahan yang diberikan kepada Qarun. Allah tidak akan memberikan balasan surga kecuali kepada orang-orang yang sabar. tsawāb sebagai alat pendidikan yang diberikan Allah kepada orang yang sabar. Untuk memotivasi hambanya dalam menjalankan ketaatan dan dalam menjauhi maksiat.

c. Ganjaran Pahala kepada Orang-Orang yang Bersyukur.

Ganjaran pahala bagi orang-orang bersyukur digambarkan oleh Allah dalam Alquransurat Ali-Imran/3 ayat: 145 bahwa bagi mereka itu adalah pahala dunia dan pahala akhirat, pahala dunia bisa berntuk apapun yangmenjadi keinginan mereka, kekayaan,pangkat, kedudukan yang tinggi dan kemegahan, asalkan mereka berusaha untuk mendapatkan itu. Jika mereka menginginkan pahala akhirat berupa surga, maka Allah juga akan berikan surga sesuai dengan ketetapan-Nya. Asalkan bersyukur kepada Allah. Dalam hal ini tsawāb sebagai alat pendidikan yang diberikan Allah kepada orang yang bersyukur untuk memotivasi hambanya.

\footnotetext{
${ }^{27}$ Armai Arief, Op-Cit, h. 127
} 
d. Ganjaran Pahala kepada Orang-Orang yang Berbuat Kebaikan.

Ganjaran pahala bagi orang-orang yang berbuat kebaikan secara umum digambarkan oleh Allah dalam Alquran surat Ali-Imran/3 ayat: 148 sebagai sambutan Allah atas permohonan orang-orang yang berjuang di jalan Allah. Mereka sedemikian tulus berdoa, optimis kepada pertolongan, bersungguh-sungguh berjuang, dan taat kepada Allah dan Rasul mereka, maka karena itu Allah menganugrahi mereka pahala dunia, berupa kemenangan, kecukupan, ketenangan batin, nama baik, dan lain-lain, dan pahala yang baik di akhirat, yaitu surga, keridhahan Allah. Tsawāb sebagai alat pendidikan yang diberikan Allah kepada orang yang berbuat kebaikan untuk memotivasi hambanya dalam berbuat kebaikan.

\section{DAFTAR RUJUKAN}

Abdullah Bin Muhammad Bin 'Abdulrahman Bin Ishaq Alu Syaikh,Tafsir Ibnu Katsir, Kairo: Pustaka Imam Asy-Syafi'i, 1994.

An-Nahlawi, Abdurrahman, Prinsip-Prinsip dan Metoda Pendidikan Islam, Bandung: CV. Diponegoro, 1996.

Anshari,Hafi, dalam Buku,Bukhari Umar, Ilmu Pendidikan Islam, Batusangkar: STAIN Batusangkar Press, 2005.

Arief, Armai, Pengantar Ilmu Dan Metodologi Pendidikan Islam, Jakarta: Ciputat Pers, 2002.

Deradjat, Zakiah, dkk, Pengajaran Agama Islam, Jakarta, Bumi Aksara, 1995.

Hamka, Tafsir Al-Azhar,Jakarta: PT. Pustaka Panjimas, 1987, juz 4.

Nizar, Samsul, Filsafat Pendidikan Islam, Jakarta: Ciputat Pers, 2002.

Nizar, Samsu, Filsafat Pendidikan Islam Pendekatan Historis, Teoritis dan Praktis, Jakarta: Ciputat Pers, 2002.

Purwanto, M. Ngalim,Ilmu Pendidikan Teoritis dan Praktis, cet, ke-6, Bandung: Remaja Rosda Karya, 2009.

Shihab, M. Quraish, Tafsir Al-Misbah Pesan, Kesan, dan Keserasian Alquran, Jakarta: Lentera Hati, 2002.

Singarimbun, Masri, dan Sofain Efend, Motode Penelitian Survai, Jakarta: PT. Midas Surya Grafindo, 1989. 